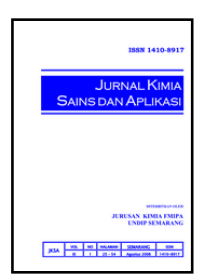

\title{
Identifikasi dan Kuantifikasi Antosianin dari Fraksi Bunga Rosela (Hibiscus Sabdariffa L) dan Pemanfaatannya sebagai Zat Warna Dye-Sensitized Solar Cell (DSSC)
}

\author{
Mitha Dea Anggistia ${ }^{a}$, Hendri Widiyandari ${ }^{\mathrm{b}}$, Khairul Anam ${ }^{\mathrm{a}}$ \\ a Organic Chemistry Laboratory, Chemistry Department, Faculty of Sciences and Mathematics, Diponegoro University, Jalan Prof. \\ Soedarto, Tembalang, Semarang \\ b Physics Department, Faculty of Sciences and Mathematics, Diponegoro University, Jalan Prof. Soedarto, Tembalang, Semarang \\ * Corresponding author: k.anam@live.undip.ac.id
}

Article Info

Keywords: anthocyanin, roselle, content, DSSC solar cells
Kata Kunci: antosianin, rosela, kadar, sel surya DSSC

\section{Abstract}

The identification of anthocyanins from the fraction of the Rosela flower (Hibiscus Sabdariffa L.) and its use as dye-sensitized solar cell dye (DSSC) has been performed. This study aims to quantify the anthocyanin levels of the rosella fraction and determine the relationship of anthocyanin levels to cell efficiency in DSSC. Methods used were: (i) anthocyanin extraction by maceration, (ii) fractionation of anthocyanin extract by column chromatography with mobile phase was water-methanol (100: 0, 75:25, 50:50, 25:75, 0: 100) and the stationary phase is sephadex LH-20, (iii) identification of anthocyanin compounds with TLC and spotting ( $\mathrm{AlCl}_{3}$ and ammonia vapor), (iv) quantification of anthocyanin levels, (v) application of anthocyanin dyes to DSSC and (vi) characterization of anthocyanin compounds in the fraction which had the highest DSSC performance using UV-Vis and IR spectroscopy. The results showed that the relative levels of anthocyanin influenced the efficiency of DSSC solar cells. The greater the relative levels of anthocyanin, the higher the efficiency of solar cells. Fraction 1 shows the relative value of anthocyanin content of $3.56 \%$ and the solar cell efficiency value of $1.014 \times 10^{-4 \%}$, while the fraction 2 shows the relative value of anthocyanin content of $40.29 \%$ and the efficiency value of the 2 nd fraction solar cell that is $6,59 \mathrm{x}$ $10^{-4 \%}$.

\section{Abstrak}

Identifikasi antosianin dari fraksi bunga Rosela (Hibiscus Sabdariffa L.) dan pemanfaatannya sebagai zat warna dye-sensitized solar cell (DSSC) telah dilakukan. Penelitian ini bertujuan untuk mengkuantifikasi kadar antosianin dari fraksi bunga rosela dan menentukan hubungan kadar antosianin terhadap efisiensi sel pada DSSC. Metode yang digunakan adalah (i) ekstraksi antosianin dengan maserasi, (ii) fraksinasi ekstrak antosianin secara kromatografi kolom dengan fasa gerak air-metanol (100:0, 75:25, 50:50, 25:75, 0:100) dan fasa diam sephadex LH-20, (iii) identifikasi senyawa antosianin dengan KLT dan penampak bercak (AlCl3 dan uap amoniak), (iv) kuantifikasi kadar antosianin, (v) aplikasi zat warna antosianin ke DSSC dan (vi) karakterisasi senyawa antosianin pada fraksi yang memiliki performansi DSSC paling tinggi menggunakan spektroskopi UV-Vis dan IR. Hasil penelitian menunjukan kadar relatif antosianin mempengaruhi nilai efisiensi sel surya DSSC. Semakin besar kadar relatif antosianin maka nilai efisiensi sel surya semakin tinggi. Fraksi 1 menunjukkan nilai kadar relatif antosianin 3,56\% dan nilai efisiensi sel surya yaitu $1,014 \times 10^{-4 \%}$, sedangkan fraksi 2 menunjukkan nilai kadar relatif antosianin 40,29\% dan nilai efisiensi sel surya fraksi 2 yaitu $6,59 \times 10^{-4} \%$. 


\section{Pendahuluan}

Krisis energi merupakan salah satu tantangan yang harus dihadapi dan diberikan solusi dengan pergeseran penggunaan sumber energi tak terbaharui menuju sumber energi yang terbaharui. Pemanfaatan energi surya menjadi energi listrik merupakan salah satu alternatif sumber energi terbaharui potensial karena posisi Indonesia pada garis khatulistiwa yang memungkinkan sinar matahari dapat optimal didapatkan di seluruh wilayah Indonesia sepanjang tahun.

Pemanfaatan teknologi energi surya yang saat ini mulai dikembangkan yaitu DSSC (Dye-sensitized Solar Cell) yang dapat mengkonversi sinar tampak menjadi energi listrik berdasarkan sensitivitas lebar bandgap dari bahan semikonduktor [1]. Spektrum absorbsi dan ikatan dye dengan permukaan $\mathrm{TiO}_{2}$ merupakan parameter penting untuk menentukan efisiensi sel. Sehingga performansi dari sel sangat bergantung pada penggunaan dye sebagai sensitizer.

Sejauh ini, dye yang digunakan berupa dye sintesis maupun dye alami. Dye sintesis yang sering digunakan yaitu jenis ruthenium complex yang harganya mahal. Selain itu, juga mengandung logam berat yang kurang menguntungkan dari aspek lingkungan. Kelemahan ini mendorong digunakannya alternatif dye alami yang diperoleh dari tumbuhan [2]. Keuntungan dye alami adalah proses isolasinya mudah, biaya produksinya murah, dan ketersediaan di alam besar [3].

Telah banyak dilaporkan bahwa antosianin dari bunga rosela (Hibiscus Sabdariffa L.) memiliki kemampuan sebagai dye-sensitizer alami karena terbukti memberikan efek photovoltaic [4]. Penelitian Okoli $d k k$. [5] telah berhasil mempelajari performa antosianin dari ekstrak rosela sebagai dye sensitizer. Abdou dkk. [6] juga telah membandingkan efisiensi sel dye antosianin dari rosela dengan dye sintetis Remazole Red dan Merocyanin. Hasilnya dye antosianin memiliki efisiensi yang lebih besar dibandingkan dye sintetik, dengan nilai efisiensi sebesar 0,27\% (Rosela), 0,14\% (Remazole Red) dan $0,001 \%$ (Merocyanin). Penggunaan antosianin dengan graphene sebagai dye sensitizer DSSC juga menunjukan peningkatan nilai efisiensi dengan nilai efisiensi sebesar $0,51 \%$ [7].

Dari penelitian sebelumnya hanya digunakan ekstrak kasar sebagai dye-sensitizer. Meskipun tidak memerlukan antosianin dengan kemurnian tinggi, namun diduga semakin banyaknya antosianin akan mempengaruhi sensitifitas dari DSSC. Oleh karena itu, pada penelitian ini akan dilakukan fraksinasi dari ekstrak antosianin dan akan ditentukan fraksi yang paling efektif sebagai dye-sensitizer serta akan dianalisis hubungan kadar antosianin dengan efisiensi sel surya DSSC (Dye-sensitized Solar Cell).

\section{Metode Penelitian}

\section{Alat dan Bahan}

Seperangkat alat gelas, timbangan analitis, satu set kromatografi kolom, vacuum rotary evaporator (Buchi R124), freeze dryer (Eyela), Plat KLT silika gel GF 254, CAMAG TLC Scanner 3, Furnace (Ney Vulcan 3-550), ultrasonic bath, multimeter digital solar simulator A.M (Air Mass), source meter (Ketley, 2400), spektrometer UVVis (T610) dan Spektrometer IR. Kelopak Rosela segar, metanol $96 \%$, HCl p.a, etanol p.a, aquades, aquabides, Sephadex LH-20, n-butanol:asamasetat:air(5:1:2), uap amoniak, $\mathrm{AlCl}_{3}$, Kaca FTO, $\mathrm{TiO}_{2}$ ukuran $20 \mathrm{~nm}, \mathrm{TiCl}_{4}$, $\mathrm{H}_{2} \mathrm{PtCl}_{6}$, elektrolite triiodide (EL-HPE), dan pasta Pt.

\section{Cara Kerja}

Ekstraksi Antosianin. Sampel kelopak bunga rosela segar sebanyak 1,5 kg dimaserasi menggunakan 4,5 L metanol dengan $\mathrm{HCl}$ 4,5 mL (1000:1). Didiamkan selama 24 jam pada suhu kamar $25^{\circ} \mathrm{C}$. Pengulangan perendaman sebanyak 3×24 jam. Hasil maserasi disaring dan dipekatkan dengan rotary evaporator suhu kurang dari $60^{\circ} \mathrm{C}[8]$.

\section{Penapisan Fitokimia}

Penapisan fitokimia dilakukan pada ekstrak pekat Rosela (Hibiscus Sabdariffa L.). Senyawa yang diidentifikasi adalah senyawa golongan alkaloid, flavonoid, saponin, tanin dan triterpenoid/steroid dan antosianin [9]

\section{Uji Alkaloid}

0,5 gram sampel ditambahkan $10 \mathrm{~mL}$ kloroform dan 5 tetes $\mathrm{NH}_{4} \mathrm{OH}$, Campuran disaring, filtratnya dikocok dan ditambahkan 10 tetes $\mathrm{H}_{2} \mathrm{SO}_{4} 2 \mathrm{M}$. Lapisan asam (atas) dibagi menjadi dua ke dalam tabung reaksi. Tabung pertama ditetesi pereaksi Dragendorff. Uji positif ditandai dengan terbentuknya warna merah atau jingga. Tabung kedua ditambahkan pereaksi Meyer. Uji positif ditandai dengan terbentuknya kabut putih hingga endapan putih.

\section{Uji Flavonoid}

Sebanyak 0,5 g sampel ditambahkan $10 \mathrm{~mL}$ metanol dan $10 \mathrm{~mL}$ akuades lalu disaring. Kemudian ditambahkan $5 \mathrm{~mL}$ eter, dikocok dan didiamkan. Lapisan metanol diuapkan pada suhu $40^{\circ} \mathrm{C}$. Kemudian dilarutkan dalam $5 \mathrm{~mL}$ etil asetat. Ditambahkan $1 \mathrm{~mL}$ etanol, 0,1 g serbuk magnesium dan $1 \mathrm{~mL}$ asam klorida pekat. Lalu dikocok kuat-kuat dan dibiarkan memisah. Adanya flavonoid ditunjukkan dengan timbulnya warna merah, kuning.

\section{Uji Saponin}

Sebanyak 0,5 g sampel ditambahkan $10 \mathrm{~mL}$ akuades panas, didihkan selama 10 menit dan disaring. Larutan dikocok kuat secara vertikal selama 10 detik. Adanya saponin ditandai dengan terbentuknya busa setinggi 1$10 \mathrm{~cm}$ yang stabil sekitar 10 menit dan tidak hilang saat ditambahkan 1 tetes asam klorida $2 \mathrm{~N}$. 


\section{Uji Tanin}

Sebanyak 0,5 g sampel ditambahkan $10 \mathrm{~mL}$ akuades panas, didihkan selama 10 menit dan di saring. Ditambahkan larutan besi(III)klorida 1\%. Adanya tanin bebas ditandai dengan terbentuknya warna hijau kehitaman.

\section{Uji Triterpenoid/Steroid}

Sebanyak 0,5 g sampel ditambahkan dengan $5 \mathrm{~mL}$ etanol panas selama 1 jam, disaring dan residunya ditambahkan eter. Ekstrak ditambahkan 3 tetes anhidrida asam asetat dan 1 tetes asam sulfat pekat. Adanya steroid ditunjukkan jika terbentuk warna biru atau ungu, sedangkan bila terbentuk warna merah menandakan adanya triterpenoid

\section{Uji Antosianin}

Sebanyak 0,5 g sampel ditambahkan $\mathrm{HCl} 2 \mathrm{M}$ dipanaskan $100^{\circ} \mathrm{C}$ selama 5 menit. Hasil positif bila timbul warna merah. Kemudian ditambahkan $\mathrm{NaOH} 2 \mathrm{M}$ tetes demi tetes sambil diamati perubahan warna yang terjadi. Hasil positif bila timbul warna hijau biru.

\section{Fraksinasi Ekstrak Antosianin dengan Metode Kolom}

Ekstrak pekat rosela sebanyak 2 gram difraksinasi dengan kromatografi kolom. Fasa diam sephadex LH-20 dan fasa geraknya metanol-air dengan perbandingan 0:100 (fraksi 1), 25:75 (fraksi 2), 50:50 (fraksi 3), 75:25 (fraksi 4), 0:100 (fraksi 5). Setiap fraksi dielusi dengan eluennya sampai bening. Hasil Fraksi diuapkan menggunakan rotary evaporator untuk menghilangkan pelarut metanol dan dihilangkan sisa pelarut airnya menggunakan freeze-dryer.

Pembuatan Larutan Fraksi dengan Konsentrasi $1000 \mathrm{ppm}$. Setiap fraksi sebanyak 0,01 gram dilarutkan ke etanol p.a dalam labu ukur $10 \mathrm{~mL}$.

\section{Identifikasi Senyawa Antosianin}

Identifikasi kandungan antosianin dilakukan dengan kromatografi lapis tipis dan penampak bercak $\left(\mathrm{AlCl}_{3}\right.$ dan uap amoniak). KLT dilakukan menggunakan fasa diam silika gel GF 254 dan fasa gerak nbutanol:asam asetat:air perbandingan 5:1:2 [9].

\section{Kuantifikasi Kadar Antosianin}

Fraksi yang menunjukan adanya noda antosianin ditentukan kuantitas antosianinnya menggunakan TLC scanner $(\lambda: 365 \mathrm{~nm})$. Ukuran penotolan ekstrak sampel pada plat KLT yaitu $10 \mu \mathrm{L}$ pada masing-masing fraksi.

\section{Aplikasi Dye Antosianin pada DSSC}

\section{Karakterisasi spektrum dye fraksi antosianin} menggunakan Spektroskopi UV-Vis

Masing-masing dye diukur pada 1000 ppm dengan 5 kali pengenceran pada fraksi 1 (0:100), 15 kali pengenceran pada fraksi 2 (25:75) dan 3 kali pengenceran pada fraksi 3 (50:50) [6].
Pelapisan kaca FTO dengan $\mathrm{TiCl}_{4}$.

Kaca FTO $(2,5 \times 2,5 \mathrm{~cm})$ dicuci dengan etanol $70 \%$ dan aquabides menggunakan ultrasonic bath pada suhu $15^{\circ} \mathrm{C}$ selama 10 menit. Perendaman kaca FTO pada $\mathrm{TiCl}_{4}$ selama 30 menit dengan suhu $70^{\circ} \mathrm{C}$. Kemudian dikeringkan dan dicuci kembali menggunakan etanol dan aquabides [10].

\section{Pembuatan elektroda kerja}

Kaca FTO dilapisi dengan pasta $\mathrm{TiO}_{2}$ (2x pelapisan) menggunakan metode Doctor Blade (ukuran permukaan aktif titania $1 \mathrm{x} 1 \mathrm{~cm}$ ). Lalu dikeringkan diatas hotplate selama 6 menit pada suhu $125^{\circ} \mathrm{C}$. Kemudian kaca FTO yang telah dilapisi dikeringkan mnggunakan furnace pada suhu $325^{\circ} \mathrm{C}$ (5 menit), $375^{\circ} \mathrm{C}$ (5 menit), $450{ }^{\circ} \mathrm{C}(15$ menit) dan $500^{\circ} \mathrm{C}(15$ menit). Didinginkan hingga suhu $\pm 30^{\circ} \mathrm{C}$ lalu direndam dengan dye antosianin [10].

\section{Pembuatan counter katalis elektroda}

Kaca FTO dilubangi dengan sand-blasting. Kemudian dicuci dengan aquades, 0,1 $\mathrm{M} \mathrm{HCl}$ dalam etanol dan acetone secara berturut-turut. Lalu kaca FTO yang sudah bersih dipanaskan pada suhu $400^{\circ} \mathrm{C}$ selama 15 menit. Kaca FTO dilapisi dengan $\mathrm{H}_{2} \mathrm{PtCl}_{6}$ pada permukaannya menggunakan metode Doctor Blade (ukuran permukaan aktif titania 1x1cm). Lalu dipanaskan kembali pada suhu $400^{\circ} \mathrm{C}$ selama 15 menit [10].

\section{Assembling Dye-sensitized Solar Cell}

Sebuah elektroda kerja dan sebuah counter katalis elektroda dirangkai membentuk struktur sandwich. Kemudian direkatkan dengan termoplastik. Prototipe DSSC dimasukan elektrolit triiodide (EL-HPE) [10].

\section{Karakterisasi unjuk kerja DSSC}

Kemudian prototipe diuji dengan Solar Simulator A.M (Air Mass) 1,5 G setara dengan intensitas daya 100 $\mathrm{mW} / \mathrm{cm}^{2}$ dan Source meter Keitley 2400. Data yang didapatkan ditentukan nilai fill factor dan nilai efisiensinya [10].

\section{Karakterisasi Senyawa Antosianin}

Fraksi yang paling baik performanya sebagai DSSC akan diisolasi komponen senyawa utamanya menggunakan metode KLT preparatif dan dikarakterisasi dengan spektroskopi UV-Vis dan spektroskopi IR.

\section{Hasil dan Pembahasan}

\section{Ekstraksi Antosianin dan Uji Fitokimia}

Sampel yang digunakan pada penelitian ini adalah 1,5 kg kelopak bunga rosela (Hibiscus Sabdariffa L.) segar yang diperoleh dari perkebunan rosela di Wonosobo. Penggunaan rosela segar bertujuan untuk mendapatkan kadar antosianin yang optimal. Kadar antosianin yang terdapat pada kelopak rosela segar lebih tinggi dibandingkan dengan rosela kering [11].

Ekstraksi kelopak bunga rosela dilakukan menggunakan metode maserasi pada temperatur kamar 
$\left(25^{\circ} \mathrm{C}\right)$ selama 24 jam dengan 3 kali pengulangan. Pemilihan metode ekstraksi ini karena sifat dari antosianin yang mudah terdegradasi oleh panas, metode ini sederhana, mudah serta cukup efisien. Berdasarkan penelitian yang dilakukan oleh Suzery $d k k$. [12], metode ekstraksi antosianin dari kelopak bunga rosela dengan maserasi pada suhu kamar $\left(25^{\circ} \mathrm{C}\right)$ memberikan rendemen ekstrak dan total antosianin yang paling tinggi dibandingkan maserasi pada suhu $5^{\circ} \mathrm{C}$ dan soxhletasi.

Ekstrak pekat antosianin yang didapatkan sebanyak 61,18 gram. Jadi berdasarkan hasil perhitungan didapatkan rendemen sebesar 4,07\%. Berdasarkan uji fitokimia diketahui ekstrak pekat kelopak bunga rosela (Hibiscus Sabdariffa L.) mengandung senyawa metabolit sekunder: flavonoid, antosianin, saponin dan tanin.

\section{Fraksinasi Ekstrak Antosianin}

Ekstrak pekat kelopak bunga rosela yang sudah diperoleh selanjutnya dilakukan fraksinasi secara kromatografi kolom. Fasa diam yang digunakan yaitu sephadex LH-20 dan fasa geraknya metanol-air dengan perbandingan 0:100 (fraksi 1), 25:75 (fraksi 2), 50:50 (fraksi 3), 75:25 (fraksi 4), 100:0 (fraksi 5). Pengelompokan ini berdasarkan ukuran dari senyawa yang ada pada ekstrak. Senyawa yang memiliki ukuran besar akan keluar terlebih dahulu pada fraksi satu dengan perbandingan metanol-air 0:100, dan seterusnya secara bertahap senyawa yang memiliki ukuran lebih kecil akan keluar pada fraksi ke 2, 3, 4 dan 5.

Prinsip pemisahan kromatografi sephadex LH- 20 adalah molekul yang berat molekul kecil akan melewati dan terjebak dalam gel sephadex terlebih dahulu sebelum turun keluar kolom, sedangkan molekul yang berat molekul besar akan langsung terelusi keluar kolom karena tidak dapat menembus gel. Oleh karena itu, molekul yang akan keluar dari kolom terlebih dahulu adalah molekul yang ukurannya lebih besar setelah itu disusul oleh molekul yang ukurannya lebih kecil [13].

Hasil fraksinasi yang didapatkan, di uji antosianin untuk mengetahui fraksi yang mengandung antosianin. Hasilnya menunjukan bahwa fraksi 1, 2 dan 3 mengandung antosianin. Sedangkan fraksi 4 dan 5 tidak mengandung antosianin. Uji positif adanya antosianin ditunjukan dengan timbulnya warna merah setelah penambahan asam yaitu $\mathrm{HCl}$ dan berubah warna hijaubiru setelah penambahan basa yaitu $\mathrm{NaOH}$ [9]. Hal ini sesuai dengan sifat antosianin yang menampakkan warna merah bila berada pada medium dengan $\mathrm{pH} 3-4$, tapi akan berubah menjadi violet jika $\mathrm{pH}$-nya meningkat. Serbuk yang diperoleh dari fraksi 1-3 yaitu 12,6570 gram, 0,2565 gram, dan 0,0606 gram.

\section{Identifikasi Senyawa Antosianin}

Identifikasi antosianin dalam fraksi 1-3 dilakukan dengan Kromatografi lapis tipis (KLT) dan penampak bercak ( $\mathrm{AlCl}_{3}$ dan uap amoniak). Data yang diperoleh dari hasil KLT pada fraksi 1-3 ditampilkan pada tabel 1.
Penampak bercak yang digunakan uap amoniak dan $\mathrm{AlCl}_{3}$. Penampak bercak ini pernah digunakan oleh Aligitha [14] untuk mengidentifikasi antosianin dari ketan hitam. Perubahan warna menjadi biru setelah diuapkan amoniak menunjukan positif antosianin yang termasuk golongan flavonoid. Perubahan warna ini karena adanya interaksi uap amoniak dengan gugus hidroksil pada flavonoid [15]. Perubahan warna menjadi kuning setelah penyemprotan dengan $\mathrm{AlCl}_{3}$ karena adanya pembentukan kompleks antara gugus hidroksil dengan logam Al [15].

Tabel 1: Hasil identifikasi antosianin secara KLT pada fraksi 1-3 dari ekstrak kelopak bunga rosela (Hibiscus Sabdariffa L.)

\begin{tabular}{|c|c|c|c|c|c|}
\hline Fraksi & $\mathrm{Rf}$ & $\begin{array}{c}\text { Warna } \\
\text { noda } \\
\lambda 365 \mathrm{~nm}\end{array}$ & $\begin{array}{c}\text { Warna } \\
\text { noda } \\
\lambda 365 \mathrm{~nm} \\
\text { setelah } \\
\text { disemprot } \\
\mathrm{AlCl}_{3}\end{array}$ & $\begin{array}{c}\text { Warna } \\
\text { noda } \\
\lambda 365 \\
\mathrm{~nm} \\
\text { setelah } \\
\text { diuapi } \\
\text { amoniak }\end{array}$ & $\begin{array}{c}\text { Diduga } \\
\text { positif } \\
\text { antosianin }\end{array}$ \\
\hline 1 & $\begin{array}{l}0,93 \\
0,57 \\
0,43\end{array}$ & $\begin{array}{c}\text { Kuning } \\
\text { flourisensi } \\
\text { Biru } \\
\text { Biru }\end{array}$ & $\begin{array}{l}\text { Kuning } \\
\text { Redup } \\
\text { Kuning }\end{array}$ & $\begin{array}{c}\text { Biru } \\
- \\
-\end{array}$ & $\begin{array}{l}+ \\
- \\
-\end{array}$ \\
\hline 2 & $\begin{array}{l}0,90 \\
0,70 \\
0,60 \\
0,56 \\
0,47 \\
0,39\end{array}$ & $\begin{array}{c}\text { Kuning } \\
\text { flourisensi } \\
\text { Merah } \\
\text { jingga } \\
\text { redup } \\
\text { Kuning } \\
\text { flourisensi } \\
\text { Biru } \\
\text { kekuningan } \\
\text { Biru } \\
\text { kekuningan } \\
\text { Biru }\end{array}$ & $\begin{array}{c}\text { Kuning } \\
\text { terang } \\
\text { Merah } \\
\text { Kuning } \\
\text { terang } \\
\text { Kuning } \\
\text { Kuning } \\
\text { kuning }\end{array}$ & $\begin{array}{c}\text { Biru } \\
\text { terang } \\
\text { Biru } \\
\text { Biru } \\
\text { terang } \\
\text { Biru } \\
\text { Biru } \\
-\end{array}$ & $\begin{array}{l}+ \\
+ \\
+ \\
+ \\
+ \\
-\end{array}$ \\
\hline 3 & 0,95 & $\begin{array}{c}\text { Biru } \\
\text { kekuningan } \\
\text { flourisensi }\end{array}$ & Redup & Biru & - \\
\hline
\end{tabular}

Kuantifikasi Kadar Antosianin

Noda yang diduga antosianin dibandingkan nilai Rf-nya dan ditentukan kadar masing-masing noda dengan data hasil TLC scanner. Data hasil TLC scanner akan menunjukan besarnya kadar relatif suatu senyawa pada sampel.

Tabel 2: Hasil kuantifikasi kadar relatif antosianin pada fraksi ekstrak kelopak bunga rosela (Hibiscus Sabdariffa L.)

\begin{tabular}{cccccc}
\hline Fraksi & $\begin{array}{c}\text { Banyak } \\
\text { penotolan } \\
(\mu \mathrm{L})\end{array}$ & Rf & $\begin{array}{c}\text { Luas } \\
\text { Area }\end{array}$ & $\begin{array}{c}\% \\
\text { Area }\end{array}$ & $\begin{array}{c}\text { \% Total Area } \\
\text { Antosianin }\end{array}$ \\
\hline 1 & 10 & 0,93 & 358,5 & 3,56 & 3,56 \\
2 & 10 & 0,90 & 530,4 & 5,87 & 40,29 \\
& & 0,70 & 272,2 & 3,01 & \\
& & 0,60 & 321,7 & 3,56 & \\
& & 0,56 & 330,7 & 3,66 & \\
\hline
\end{tabular}

*) Konsentrasi larutan dalam 1000 ppm

Dari data diatas menunjukan fraksi 2 memiliki kadar relatif lebih besar dibandingkan fraksi 1 . 
Persentase total area antosianin fraksi 1 yaitu 3,56\% sedangkan fraksi 2 yaitu 40,29\%.

\section{Aplikasi Dye Antosianin pada DSSC}

\section{Karakteristik Absorbansi Dye Fraksi Antosianin Bunga Rosela}

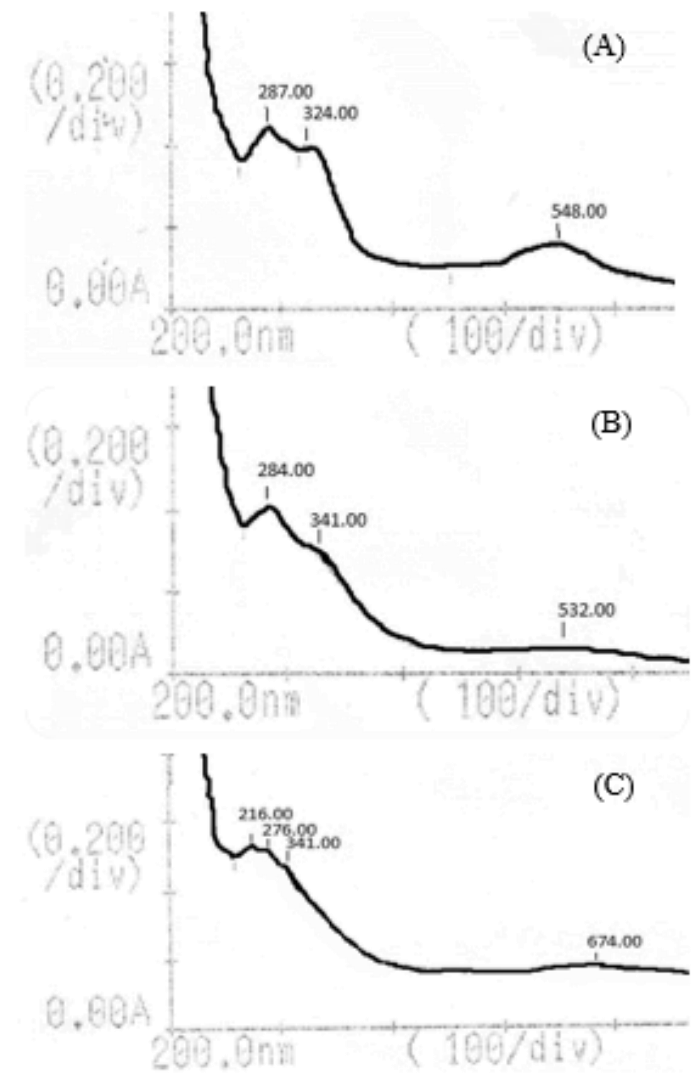

Gambar 1. Spektrum absorbsi fraksi 1(A), fraksi 2(B), dan fraksi 3(C) ekstrak rosela

Hasil karakterisasi spektrum UV-Vis pada gambar 2 memperlihatkan adanya serapan pada daerah UV (200$400 \mathrm{~nm}$ ) dan Visible (400-700 nm). Adanya serapan daerah visible menunjukan fraksi dapat menyerap spektrum cahaya tampak sehingga dapat diaplikasikan pada DSSC. Fraksi 1 memiliki serapan pada panjang gelombang $287 \mathrm{~nm}, 324 \mathrm{~nm}$ dan $548 \mathrm{~nm}$. Fraksi 2 memiliki serapan pada panjang gelombang $284 \mathrm{~nm}, 341^{\circ}$ $\mathrm{nm}$ dan $532 \mathrm{~nm}$. Serapan fraksi 1-2 pada daerah visible $548 \mathrm{~nm} 532 \mathrm{~nm}$ menunjukan bahwa kedua fraksi menyerap spektrum hijau (495-570 nm). Sedangkan fraksi 3 memiliki serapan pada panjang gelombang 213 nm, 276 nm, $341 \mathrm{~nm}$, dan $674 \mathrm{~nm}$. Fraksi 3 menunjukan menyerap spektrum merah (620-750 nm).

\section{Karakteristik Arus dan Tegangan Dye-sensitized Solar Cell (DSSC)}

Elektroda kerja yang telah dilapisi oleh nanopartikel $\mathrm{TiO}_{2}$ ukuran $20 \mathrm{~nm}$ direndam masing-masing pada fraksi 1 dan fraksi 2 yang memiliki konsentrasi sama yaitu $1000 \mathrm{ppm}$. Proses perendaman dilakukan selama 24 jam. Kemudian elektroda kerja dan counter katalis elektroda disusun dengan struktur sandwich menjadi prototipe sel surya DSSC..
Prototipe sel surya DSSC yang telah dibuat diuji karakteristik arus dan tegangannya (I-V) menggunakan alat Solar Simulator A.M (Air Mass) 1,5 G setara dengan intensitas daya $100 \mathrm{~mW} / \mathrm{cm}^{2}$ dan Source meter Keitley 2400. Uji ini dilakukan untuk mengetahui kinerja sel surya DSSC.

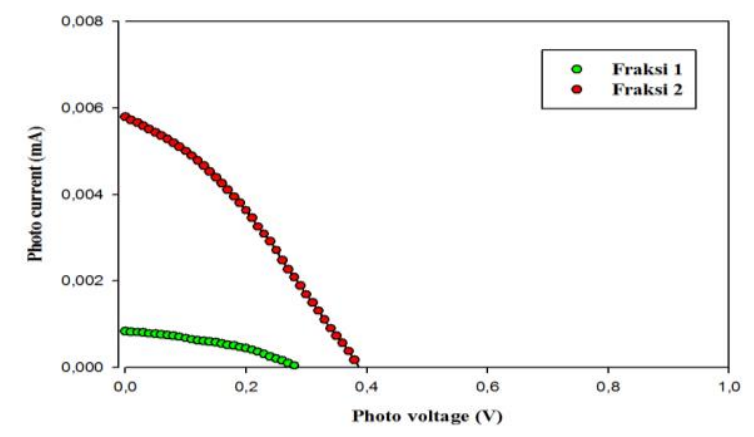

Gambar 2. Grafik I-V (Arus-Tegangan) prototipe sel surya fraksi 1 dan 2

Berdasarkan data grafik I-V (Arus-Tegangan) dan perhitungan, maka didapatkan nilai $\mathrm{I}_{\mathrm{sc}}, \mathrm{J}_{\mathrm{sc}}, \mathrm{V}_{\mathrm{oc}}, \mathrm{I}_{\mathrm{max}}, \mathrm{V}_{\mathrm{max}}$, $\eta$ dan FF sebagai berikut:

Tabel 3: Hasil pengukuran parameter fotovoltaik dari prototipe sel surya DSSC

\begin{tabular}{|c|c|c|c|c|c|}
\hline Fraksi & $\begin{array}{c}\text { Voc } \\
\text { (Volt) }\end{array}$ & \multicolumn{2}{|c|}{$\begin{array}{c}\text { Isc } \\
(\mathrm{mA})\end{array}$} & $\begin{array}{c}\text { Jsc } \\
(\mathrm{mA} / \mathrm{cm} 2)\end{array}$ & $\begin{array}{l}\operatorname{Imax} \\
(\mathrm{mA})\end{array}$ \\
\hline 1 & 0,2900 & \multicolumn{2}{|c|}{0,0008} & 0,0008 & 0,0006 \\
\hline 2 & 0,3900 & \multicolumn{2}{|c|}{0,0058} & 0,0058 & 0,0048 \\
\hline $\begin{array}{l}\text { Vmax } \\
\text { (Volt) }\end{array}$ & \multicolumn{2}{|c|}{$\begin{array}{l}P \max \\
(\mathrm{mW})\end{array}$} & \multicolumn{2}{|c|}{$\begin{array}{c}\text { Efisiensi } \\
(\%) \\
\eta\end{array}$} & FF \\
\hline 0,1690 & \multicolumn{2}{|c|}{$\begin{array}{c}1,014 \times 10- \\
4\end{array}$} & & $14 \times 10-4$ & 0,437 \\
\hline 0,1373 & \multicolumn{2}{|c|}{$\begin{array}{c}6,590 \times 10- \\
4\end{array}$} & & $90 \times 10-4$ & 0,291 \\
\hline
\end{tabular}

*) Luas area pengukuran $1 \mathrm{~cm}^{2}$

*) Konsentrasi larutan dalam 1000 ppm

Ket $:$ Voc = Tegangan open circuit ,Vmax= Tegangan maksimum, Pmax = Daya maksimum. Isc=Arus short circuit, Jsc=Rapat arus short circuit, FF= Fill factor

Hasil yang didapatkan menunjukan bahwa fraksi 2 memiliki performa yang lebih baik sebagai DSSC (Dyesenstized Solar Cell) karena tingkat efisiensinya yang lebih tinggi dibandingkan efisiensi pada fraksi 1.

\section{Karakterisasi Senyawa Antosianin}

Aplikasi DSSC (Dye-senstized Solar Cell) dari dye antosianin fraksi 2 memiliki performa yang lebih tinggi sebagai DSSC (Dye-senstized Solar Cell) dibandingkan fraksi 1. Hal ini juga didukung dari kuantifikasi kadar relatif antosianin yang menunjukan fraksi 2 memiliki kadar relatif antosianin yang lebih besar dibandingkan fraksi 1. Oleh karena itu, perlu dilakukan karakterisasi senyawa antosianin pada fraksi 2 untuk mendukung identifikasi antosianin.

Selanjutnya dilakukan KLT preparatif pada fraksi 2. Setelah dielusi dengan BAW (5:1:2), maka dikerok 2 noda 
(Rf:0,9 dan Rf:0,6) yang diduga antosianin dan dilarutkan ke etanol p.a. Pemilihan kedua noda tersebut karena warna noda memiliki intensitas paling kuat.

Uji kemurnian dilakukan dengan KLT menggunakan berbagai pelarut sebagai fasa gerak dan silika GF 254 sebagai fasa diam. Pelarut yang digunakan yaitu metanol (polar), etil asetat (semipolar), kloroform (nonpolar) dan $\mathrm{n}$-heksan (nonpolar). Setelah dielusi dengan berbagai pelarut (eluen tunggal dan eluen campuran), diketahui isolat 0,9 dan 0,6 merupakan senyawa murni. Kedua isolat ini dikarakterisasi menggunakan spektrofotometer IR dan UV-Vis.

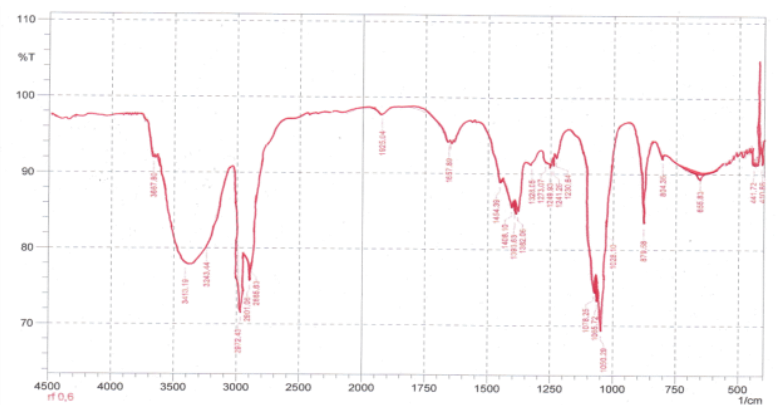

Gambar 3. Spektrum spektroskopi inframerah isolat Rf 0,60 dari fraksi 2 ekstrak kelopak bunga rosela

Hasil analisis isolat $\mathrm{Rf} 0,60$ dengan spektrofotometer IR diketahui adanya serapan tajam dengan intensitas lemah pada daerah panjang gelombang $3667,80 \mathrm{~cm}^{-1}$ diduga adalah serapan ulur dari gugus $-\mathrm{OH}$ bebas. Serapan melebar dengan intensitas sedang pada daerah panjang gelombang $3413,19 \mathrm{~cm}^{-1}$ dan $3243,44 \mathrm{~cm}^{-1}$ diduga dari serapan ulur gugus $\mathrm{O}-\mathrm{H}$ yang dapat membentuk ikatan hidrogen. Serapan ulur dari gugus $\mathrm{C}-\mathrm{H}$ alifatik yang tajam dan kuat muncul pada daerah bilangan gelombang 2972,43 $\mathrm{cm}^{-1}, 2901,06 \mathrm{~cm}^{-1}, 2885,63 \mathrm{~cm}^{-1}$. Adanya gugus karbonil $\left(-\mathrm{C}=\mathrm{O}^{+}\right)$sebagai ciri umum senyawa antosianin diindikasikan oleh adanya serapan pada daerah bilangan gelombang $1657,00 \mathrm{~cm}^{-1}$. Serapan ulur $\mathrm{C}-\mathrm{H}$ tekuk alifatik muncul pada daerah bilangan gelombang $1454,39 \mathrm{~cm}^{-1}, 1408,10 \mathrm{~cm}^{-1}, 1393,63 \mathrm{~cm}^{-1}$, dan 1382,06 cm${ }^{1}$. Vibrasi ulur C-O dalam senyawaan fenol menghasilkan pita kuat di daerah 1260-1000 $\mathrm{cm}^{-1}$ [16]. Pada isolat serapan $\mathrm{C}-\mathrm{O}$ muncul pada daerah bilangan gelombang $1249,93 \mathrm{~cm}^{-1}$ dengan pita tajam dan lemah. Serapan C$\mathrm{OH}$ pada $1050,29 \mathrm{~cm}^{-1}$ dengan pita tajam dan kuat. Serapan pada bilangan gelombang $879,68 \mathrm{~cm}^{-1}, 804,36$ $\mathrm{cm}^{-1}$, dan $655,83 \mathrm{~cm}^{-1}$ menunjukan adanya substitusi pada benzena.

Selanjutnya isolat $\mathrm{Rf} \quad 0,6$ dikarakterisasi menggunakan spektrofotometer UV-Vis.

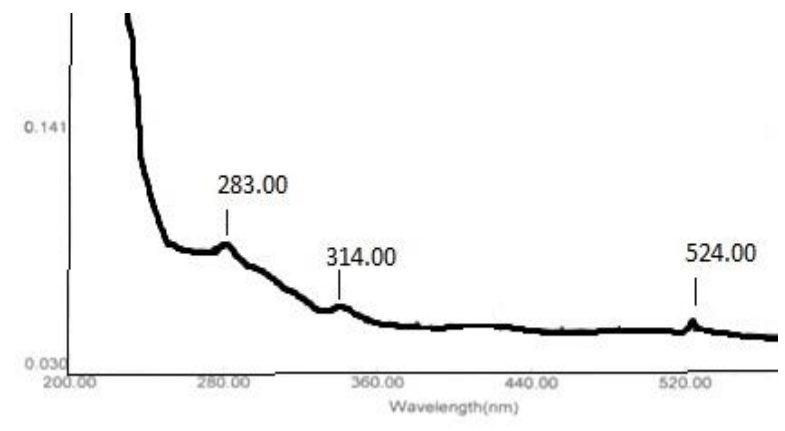

Gambar 4. Spektrum UV-Vis isolat Rf 0,60 dari fraksi 2 ekstrak kelopak bunga rosela

Sifat khas spektrum antosianin menurut Markham [15] terdapat puncak pita $1(\lambda$ 465-560) dan pita $2(\lambda$ 270-280). Sedangkan menurut Harborne [9] terdapat puncak pita 1 ( $\lambda$ 475-560) dan pita $2(\lambda \pm 275)$. Isolat $\mathrm{Rf}$ 0,6 memberikan serapan khas yang menunjukan antosianin karena menyerap pada panjang gelombang $283 \mathrm{~nm}, 314 \mathrm{~nm}$ dan $524 \mathrm{~nm}$. Serapan ini sesuai dengan penelitian Supiyanti $d k k$. [17] pada spektrum UV hasil KLT preparatif dari antosianin kulit buah manggis yang menunjukan adanya serapan pada panjang gelombang $279 \mathrm{~nm}, 317 \mathrm{~nm}$ dan $525 \mathrm{~nm}$. Hasil tersebut juga didukung oleh Jordheim [18] yang mengukur spektrum senyawa antosianin golongan sianidin pada biji jarak (Ricinus communis) mempunyai serapan maksimal pada panjang gelombang $283 \mathrm{~nm}, 314 \mathrm{~nm}$ dan $522 \mathrm{~nm}$.

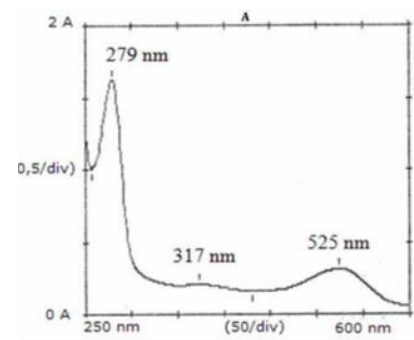

(a)

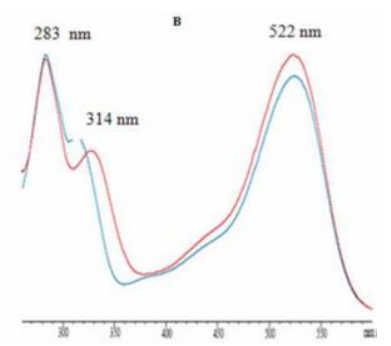

(b)
Gambar 5. Spektrum UV-Vis antosianin dari (a) kulit buah manggis [17] dan (b) sianidin pada biji jarak [18]

Berdasarkan informasi yang didapatkan dari spektroskopi inframerah dan spektroskopi UV-Vis, isolat $\mathrm{Rf}$ 0,6 diduga senyawa antosianin. Ini didukung dengan adanya gugus fungsi $-\mathrm{OH}$ bebas, $\mathrm{O}-\mathrm{H}$ yang dapat berikatan hidrogen, $\mathrm{C}-\mathrm{H}$ alifatik, $\mathrm{C}-\mathrm{H}$ tekuk alifatik, gugus karbonil $\left(-\mathrm{C}=\mathrm{O}^{+}\right)$, gugus $\mathrm{C}-\mathrm{O}$ dan substitusi benzena. Gugus tersebut merupakan gugus yang terdapat pada kerangka utama antosianin. Dugaan ini diperkuat dengan informasi spektrum UV-Vis yang memiiki serapan khas antosianin yaitu pada panjang gelombang $283 \mathrm{~nm}, 314 \mathrm{~nm}$ dan $524 \mathrm{~nm}$. 


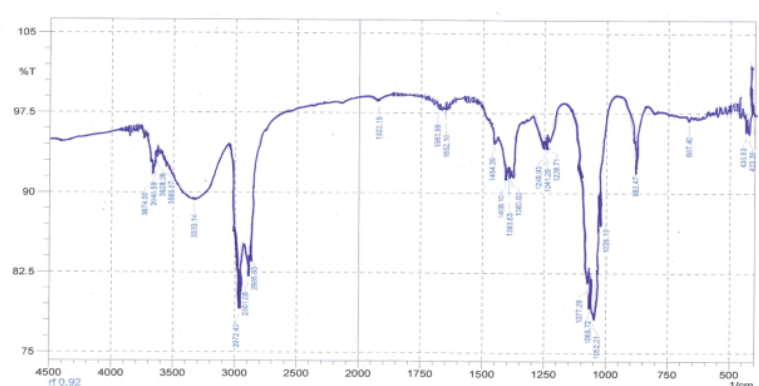

Gambar 6. Spektrum spektroskopi inframerah isolat Rf 0,90 dari fraksi 2 ekstrak kelopak bunga rosela

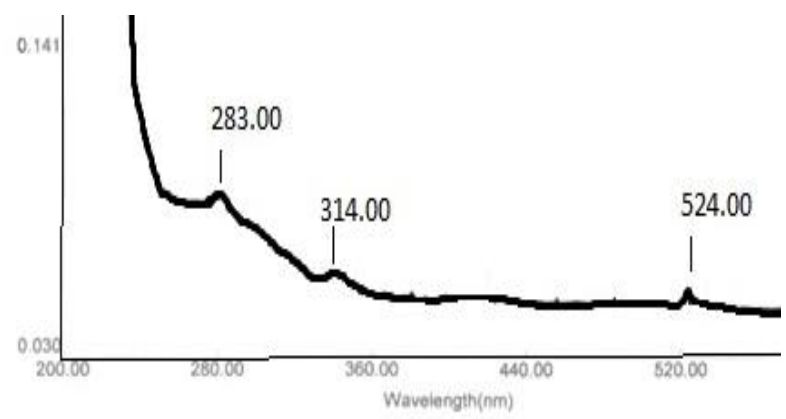

Gambar 7. Spektrum UV-Vis isolat Rf 0,90 dari fraksi 2 ekstrak kelopak bunga rosela

Isolat $\mathrm{Rf} 0,9$ juga diduga senyawa antosianin. Karena memiliki kesamaan gugus dengan isolat $\mathrm{Rf}$ 0,6 yaitu adanya gugus fungsi - $\mathrm{OH}$ bebas, $\mathrm{O}-\mathrm{H}$ yang dapat berikatan hidrogen, $\mathrm{C}-\mathrm{H}$ alifatik, $\mathrm{C}-\mathrm{H}$ tekuk alifatik, gugus karbonil $\left(-\mathrm{C}=\mathrm{O}^{+}\right)$, gugus $\mathrm{C}-\mathrm{O}$ dan substitusi benzena. Dugaan ini diperkuat dengan informasi spektrum UV-Vis yang memiiki serapan khas antosianin yaitu pada panjang gelombang $271 \mathrm{~nm}, 330 \mathrm{~nm}$, dan 534 $\mathrm{nm}$

\section{Kesimpulan}

Berdasarkan penelitian yang dilakukan pada ekstrak antosianin bunga rosela (Hibiscus Sabdariffa L.) dapat disimpulkan bahwa pada konsentrasi 1000 ppm, kadar relatif total antosianin fraksi 2 lebih besar dibandingkan fraksi 1 . Total area antosianin fraksi 1 yaitu 3,56 \% sedangkan fraksi 2 yaitu 40,29\%. Kadar relatif antosianin mempengaruhi nilai efisiensi sel surya DSSC (Dye-sensitized Solar Cell). Semakin besar kadar relatif antosianin maka nilai efisiensi sel surya semakin tinggi. Nilai efisiensi sel surya fraksi 1 yaitu $1,014 \times 10^{-4} \%$ sedangkan sel surya fraksi 2 yaitu $6,590 \times 10^{-4} \%$.

\section{Daftar Pustaka}

[1] Catur Hilman, A Sa'diah, Analisis Pemanfaatan Anthocyanin Tumbuhan Tropis sebagai Sensitizer pada Dye-Sensitized Solar Cell (DSSC), Seminar Nasional Material, (2013).

[2] Akhiruddin Maddu, Mahfuddin Zuhri, Irmansyah Irmansyah, Penggunaan Ekstrak Antosianin Kol Merah Sebagai Fotosensitizer pada Sel Surya TiO2 Nanokristal Tersensitisasi Dye, Makara, 11, 2, (2009) $78-84$

[3] Laila Ika Anggraini, Abdul Haris, Didik Setiyo Widodo, Pembuatan Dye-Sensitized Solar Cell dengan Memanfaatkan Fotosensitizer Ekstrak Kol Merah (Brassica oleracea var. capitata f. Rubra), Jurnal Kimia Sains dan Aplikasi, 13, 3, (2010) 101-108

[4] Khwanchit Wongcharee, Vissanu Meeyoo, Sumaeth Chavadej, Dye-sensitized solar cell using natural dyes extracted from rosella and blue pea flowers, Solar Energy Materials and Solar Cells, 91, 7, (2007) 566-571 http://dx.doi.org/10.1016/i.solmat.2006.11.005

[5] LU Okoli, JO Ozuomba, AJ Ekpunobi, PI Ekwo, Anthocyanin-dyed $\mathrm{TiO}_{2}$ electrode and its performance on dye-sensitized solar cell, Research Journal of Recent Sciences, 1, (2012) 22-27

[6] E. M. Abdou, H. S. Hafez, E. Bakir, M. S. A. AbdelMottaleb, Photostability of low cost dye-sensitized solar cells based on natural and synthetic dyes, Spectrochimica Acta Part A: Molecular and Biomolecular Spectroscopy, 115, (2013) 202-207 http://dx.doi.org/10.1016/i.saa.2013.05.090

[7] Anna Carissa M. San Esteban, Erwin P. Enriquez, Graphene-anthocyanin mixture as photosensitizer for dye-sensitized solar cell, Solar Energy, 98, (2013) 392-399 http://dx.doi.org/10.1016/j.solener.2013.09.036

[8] Luigia Longo, Anna Scardino, Giuseppe Vasapollo, Identification and quantification of anthocyanins in the berries of Pistacia lentiscus L., Phillyrea latifolia L. and Rubia peregrina L, Innovative Food Science \& Emerging Technologies, 8, 3, (2007) 360-364 http://dx.doi.org/10.1016/j.ifset.2007.03.010

[9] Jeffrey Barry Harborne, Metode fitokimia, Padmawinata K, S. I, Institut Teknologi Bandung, Bandung, 1987.

[10] Hendri Widiyandari, Agus Purwanto, Kuncoro Diharjo, Jatmiko Endro Suseno, Facile method for synthesis of TiO 2 film and its application in high efficiency dye sensitized-solar cell (DSSC), AIP Conference Proceedings, (2014).

[11] Sawarni Mardiah, Reki W Ashadi, Arifah Rahayu, Budidaya dan Pengolahan Rosela Si Merah Segudang Manfaat, Agromedia Pustaka. Jakarta, 23, (2009)

[12] Meiny Suzery, Sri Lestari, Bambang Cahyono, Penentuan Total Antosianin dari Kelopak Bunga Rosela (Hibiscus Sabdariffa L) dengan Metode Maserasi dan Sokshletasi, Jurnal Sains dan Matematika, 18, 1, (2010) 1-6

[13] Reuben Alexander Day, Arthur Louis Underwood, Analisa Kimia Kuantitatif, Erlangga, 1994.

[14] W Aligitha, Isolasi Antosianin dari Ketan Hitam (Oriza Sativa L Forma Glutinosa), J. Farmasi, 31, 1, (2007) 26-27

[15] K. R. Markham, Techniques of flavonoid identification, Academic Press, 1982.

[16] Robert M Silverstein, G Clayton Bassler, Terence C Morrill, Spectroscopic identification of organic compounds, Wiley, New York, (1981) 196

[17] Wiwin Supiyanti, E Dwi Wulansari, L Kusmita, Uji aktivitas antioksidan dan penentuan kandungan antosianin total kulit buah manggis (Garcinia mangostana L), Majalah Obat Tradisional, 15, 2, (2010) 64-70 
[18] Monica Jordheim, Isolation, identification and properties of pyranoanthocyanins and anthocyanin forms, Department of Chemistry, The University of Bergen, Norway 